\title{
Communication
}

[Comunicação]

\section{Casuistry of radiographic examinations of wild animals in the southern region of the state of Rio Grande do Sul, Brazil, from 2017 to 2020}

\author{
[Casuística dos exames radiográficos de animais silvestres na região Sul do \\ Rio Grande do Sul entre 2017-2020]

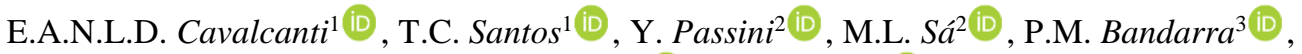 \\ G.A.O. Cavalcanti ${ }^{(i D}$, R.T. França ${ }^{4}$ (i) \\ ${ }^{1}$ Graduate, Universidade Federal de Pelotas, Pelotas, RS, Brasil \\ ${ }^{2}$ Graduate, Medicina de Animais Silvestres, Universidade Federal de Pelotas, Pelotas, RS, Brasil \\ ${ }^{3}$ Veterinarian, Universidade Federal de Pelotas, CETAS/NURFS, Pelotas, RS, Brasil \\ ${ }^{4}$ Universidade Federal de Pelotas, Pelotas, RS, Brasil
}

The radiological examination is an important diagnostic tool in different species, as it assists the veterinarian in searching a range of diseases (Thrall, 2014; Pinto, 2020). Diagnostic imaging techniques have been used in the wild animal clinic to complement the clinical examination, as free-living animals often do not have a history when they arrive at screening centers and some orders of reptiles have anatomy that makes clinical evaluation difficult (Divers and Stahl, 2019; Dutra, 2020). However, the use of other techniques of complementary image examinations has been increasing, such as ultrasound, computed tomography, and magnetic resonance, which contribute both to the quality of life and the preservation of species (Valente, 2007; Zoller et al., 2019).

Radiology is the imaging technique that stands out most in the clinical routine of wild animals (Zoller et al., 2019; Pinto, 2020), as it shows an advantageous cost-benefit, it is not invasive, allows research of several diseases, and is easy to access (Bortolini et al., 2013; Thrall, 2014; Pinto, 2020). However, radiographic examinations and other complementary diagnostic examinations should considerer specific anatomical differences of each animal, such as the absence of mesenteric fat in some reptiles (Mitchell, 2009) and the presence of free fluid in the abdominal cavity of anteaters (Lopes et al., 2015).

Acording to Romero et al. (2019) in a five-year retrospective study in Chile, the cause most frequently admitted was trauma for birds, mammals and reptiles, the second cause is systemic disorders. All causes would need radiographic examination. Moreover, these causes could change according to the region studied and the type of animals, as observed in the same study.

Considering the importance of image examination for the wild animal clinic and the lack of similar studies in the southern region of the state of Rio Grande do Sul, Brazil, a survey of the species and radiographic findings of wild animals sent to the Laboratory of Diagnostic Imaging and Cardiology (LADIC) at the Veterinary Hospital of the Federal University of Pelotas (HCV/UFPel) was carried out.

A retrospective study was done of the medical records, radiographic imaging and results of wild animals (birds, mammals, and reptiles) sent by the Wildlife Rehabilitation Center (NURFS) to the Laboratory of Diagnostic Imaging and Cardiology (LADIC) of the Veterinary Hospital of the Federal University of Pelotas (HCV/UFPel) during the period of four consecutive years (2017-2020).

The data were evaluated by separating the medical records by taxonomic class (mammals, reptiles and birds), species, and region of anatomical interest (axial skeleton, appendicular skeleton, thorax, abdomen and coelomic cavity). 


\section{Cavalcanti et al.}

A total of 464 records of wild animals were evaluated from January 2017 to December 2020. Among them, 63.1\% (293/464) corresponded to birds, $29.1 \%(135 / 464)$ to mammals and $7.8 \%$ (36/464) to reptiles. Bortolini et al. (2013) carried out a study at the university hospital in Botucatu, São Paulo, Brazil, and observed a smaller sample of birds (45\%) than our data, but mammals (37\%) and reptiles (18\%) had a higher frequency. In both studies, the highest number of medical care occurred in birds, which may be related to the higher biodiversity or higher number of seizures of trafficked animals, with birds being the most frequent victims because they have attractive characteristics for human beings (Romero et al., 2019).

The most frequent birds were owls (Megascops choliba, Glaucidium brasilianum, Tyto furcate, Asio sp., Bubo virginianus and Athene cunicularia), with a frequency of $12.6 \%$ (37/293), followed by monk parakeets (Myiopsitta monachus), with $10.2 \%(30 / 293)$ and great kiskadees (Pitangus sulphuratus), with 9.6\% (28/293).

The species of mammals with the highest occurrence consisted of white-eared opossums (Didelphis albiventris), with a frequency of $34.8 \%$ (47/135), followed by pampas foxes (Lycalopex gymnocercus), with $17 \%$ (23/135) and the Howler monkeys (Alouatta sp.), with $8.7 \%$ $(10 / 115)$.

Finally, the most frequent reptile species consisted of black-bellied sliders (Trachemys dorbigni), with a frequency of $41.7 \%$ (15/36), broad-snouted caiman (Caiman latirostris), with $16.7 \%(6 / 36)$ and black spine-neck swamp turtle (Acanthochelys spixii), with 34.9\% (5/36).

The medical records showed that most of these animals have no history (365), and the most reported causes as a reason for radiographic evaluation were run over $(7.7 \%)$, attacks by domestic animals $(5.38 \%)$, collision against the glass and other objects (3.23\%), mistreatment $(3 \%)$, and falling of the nest (1.9\%). Romero et al. (2019) pointed out the difficulty of finding in the literature the impact of anthropic action on fauna, listing accidents (run over, collision against windows, and electric shock), sport hunting (which is prohibited in Brazil), and mistreatment as factors of great impact.

The division by study area was carried out as proposed by Thrall (2014). Thus, the appendicular skeleton represented $60.8 \%(282 / 464)$ of the examinations, axial skeleton $17 \%$ (79/464), thoracic/coelomic cavity $17.7 \%(82 / 464)$, and abdominal cavity $4.5 \% \quad(21 / 464)$. The appendicular skeleton was the most evaluated region in the group of birds and mammals, while the coelomic cavity was the most evaluated in reptiles.

In total, 464 animals were radiographed. A total of 496 radiographic changes were found in these studies (Table 1). The most frequent findings in birds were wing fractures (humerus, radius-ulna, and carpus), followed by fractures in the pelvic limbs (femur and tibiotarsus) and soft tissue volume augmentation (Fig. 1). The most frequent changes in mammals were limb fractures. Moreover, the most frequent findings in reptiles were changes in pulmonary opacification, compatible with the pneumonia process.

Traumatic fractures in the appendicular skeleton were the most frequent radiographic changes caused mainly by run over (34 animals), attack by domestic animals (23 animals), collision with glass panes (16 animals), and tree/nest fall (9 animals).

Traumatic skull fractures (Fig. 2) were the most observed changes in the axial skeleton of wild animals. In contrast, Fighera et al. (2008) observed the highest frequency of spinal cord trauma in domestic canid. In this survey, human aggression was the main cause, probably related to superstitions or confusion with some species, and even attempted hunting, followed by run over. The roads in the South region cross extensive areas of agricultural cultivation and ecological reserves, such as the highway BR-471, which crosses the Taim Ecological Station. 


\section{Casuistry of radiographic...}

Table 1. Radiographic finding distributed according to the anatomical region of involvement. Casuistry of radiographic examimation of wild animals -2017 to 2020. LADIC/HCV/UFPel

\begin{tabular}{|c|c|c|}
\hline & Anatomical region & Finding \\
\hline $\begin{array}{l}\text { Appendicular skeleton } \\
(282)\end{array}$ & $\begin{array}{l}\text { Thoracic limbs } \\
\text { - Right (77) } \\
\text { - Left (73) } \\
\text { Pelvic limbs } \\
\text { - Right (51) } \\
\text { - Left (48) } \\
\text { Pelvis (33) }\end{array}$ & $\begin{array}{l}\text { Soft tissue volume augmentation (58) } \\
\text { Humerus fracture (55) } \\
\text { Radius-ulna fracture (43) } \\
\text { Femur fracture (39) } \\
\text { Tibiotarsal fractures (39) } \\
\text { Pelvis fracture (24) } \\
\text { Digit fracture (12) } \\
\text { Scapulohumeral dislocation (9) } \\
\text { Arthritis/arthrosis (7) } \\
\text { Foreign body/projectile (1) } \\
\text { Osteomyelitis (1) }\end{array}$ \\
\hline Axial skeleton (79) & $\begin{array}{l}\text { Skull (49) } \\
\text { column (30) }\end{array}$ & $\begin{array}{l}\text { Skull fracture (29) } \\
\text { Column fracture (12) } \\
\text { Foreign body/projectile (1) }\end{array}$ \\
\hline Coelomic cavity/thorax (82) & Thorax & $\begin{array}{l}\text { Pulmonary pattern change (62) } \\
\text { Rib fracture }(29) \\
\text { Coracoid fracture }(21) \\
\text { Clavicle fracture (18) } \\
\text { Plastron fracture (6) } \\
\text { Foreign body/projectile (1) }\end{array}$ \\
\hline Abdomen (21) & Abdomen & $\begin{array}{l}\text { Hepatomegaly (11) } \\
\text { Foreign body (9) } \\
\text { Free fluid (3) }\end{array}$ \\
\hline Total & 464 & 496 \\
\hline
\end{tabular}

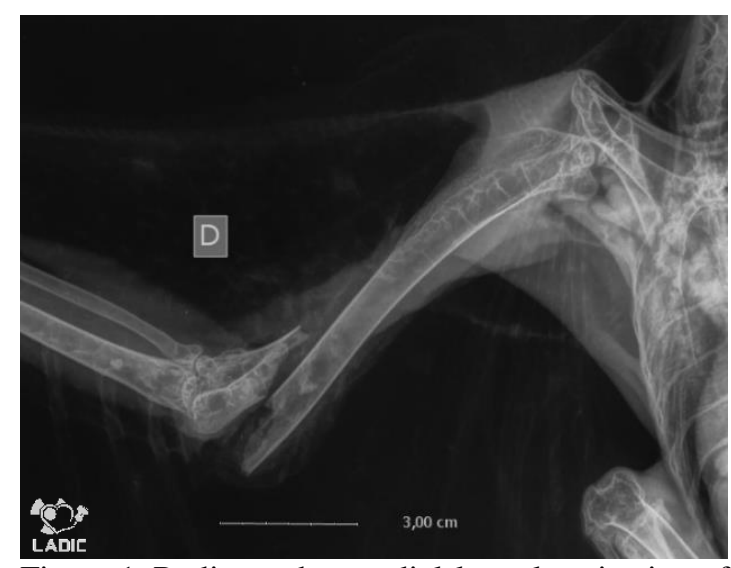

Figure 1. Radiography, medial-lateral projection of a specimen of Rupornis magnirostris. Animal with no history. A spiral fracture can be observed in the distal metaphyseal region of the right humerus.

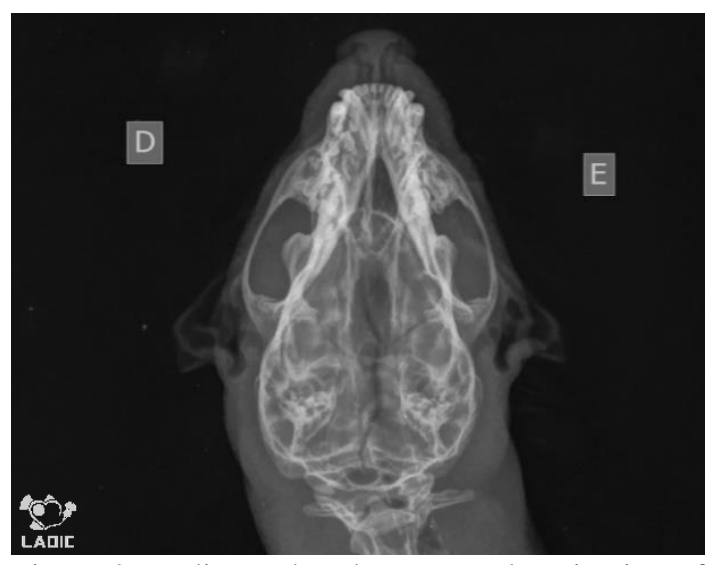

Figure 2. Radiography, dorsoventral projection of a specimen of Galictis cuja. Animal with no history. A radiolucent line extends from the occipital to the frontal sinus region, medially to the medial wall of the right orbit. 


\section{Cavalcanti et al.}

Changes in the thorax or celomic cavity in birds and reptiles were quite frequent, standing out pneumonia/aerosaculitis in birds. It differs from the casuistry pointed out by Bortolini et al. (2013) in Botucatu, who found the higher frequency in limb fractures, and Romero et al. (2019) in Chile, who observed that unspecifc osteopathies, systemic disorder were more frequent.

The highest number of changes found in the coelomic cavity of reptiles were compatible with pneumonia. According to Divers and Stahl (2019), secondary infections in the respiratory tract of reptiles are the most common, caused by different factors, such as management, nutrition, and hygiene, or other factors that lead to stress, as observed in this study in southernmost Brazil. The region observed is cold and humid. This condition, associated with other factors, predisposes to respiratory tract problems in both animals.

The evaluations of the abdomen or coelomic cavity pointed to radiopaque foreign bodies, hepatomegaly, and free abdominal fluid as the changes observed in these regions. Foreign bodies (12/464) were the most common findings to occur concurrently with other findings, showing rounded structures with metal radiopacity compatible with projectiles, as well as metal, linear, and curvilinear radiopacity structures compatible with fishhook (Fig. 3).

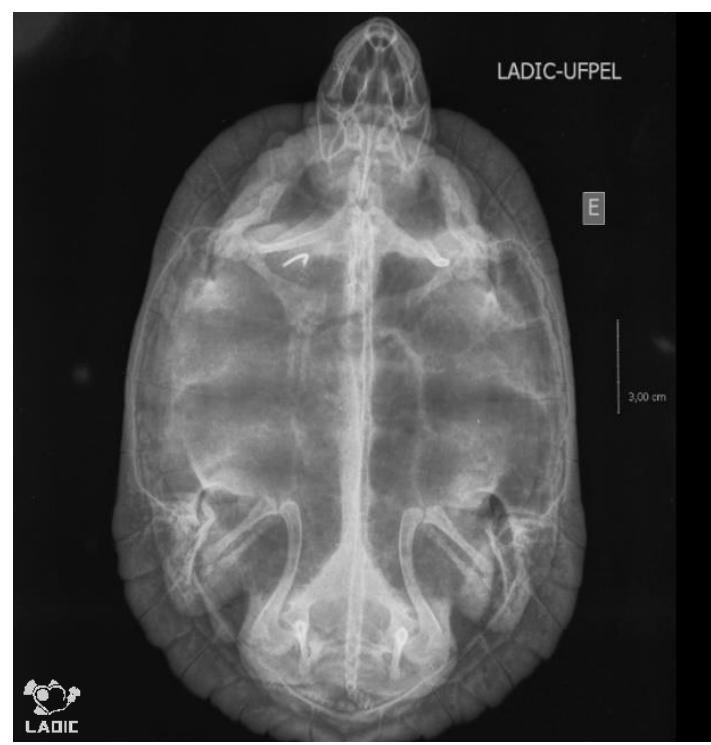

Figure 3. Radiography, dorsoventral projection of a specimen of Trachemys dorbigni. Animal referred for evaluation of missing structures in the forelimbs. A metal, linear, and curvilinear radiopacity structure (fishing hook) is observed in the esophageal topography.

The integration between imaging diagnosis and the wild animal clinic is essential as complementary diagnosis. This survey showed that the highest number of animals sent to LADIC corresponded to birds, which had wing fractures, mammals and reptiles.

Keywords: radiology, diagnostic imaging, medicine

\section{RESUMO}

A radiologia é uma importante ferramenta complementar para o diagnóstico de diversas afecções em diferentes espécies. $O$ uso de exames complementares na medicina de animais silvestres, em especial o exame de imagem, traz inúmeras informações acerca do paciente. Este trabalho apresenta os dados obtidos por meio de um levantamento dos exames radiográficos realizados em animais silvestres entre os anos de 2017 e 2020, no Laboratório de Diagnóstico de Imagem e Cardiologia (LADIC), do Hospital de Clínicas Veterinárias da Universidade Federal de Pelotas (HCV/UFPel). Ao todo, foram avaliados 464 prontuários, sendo $293(63,1 \%)$ de aves, 135 (29,1\%) de mamíferos e 36 (7,8\%) de répteis. As alterações mais encontradas nos exames radiológicos foram fratura de membros torácicos para as duas primeiras classes, e pneumonia para a última.

Palavras-chave: radiologia, diagnóstico por imagem, medicina 


\section{ACKNOWLEDGEMENTS}

This study was supported by CAPES (Coordenação de Aperfeiçoamento de Pessoal de Nível Superior) and Programa de Pós-Graduação em Veterinária - UFPEL.

\section{REFERENCES}

BORTOLINI, Z.; MATAYOSHI, P.M.; SANTOS, R.V. et al. Casuística dos exames de diagnóstico por imagem na medicina de animais selvagens - 2009 a 2010. Arq. Bras. Med. Vet. Zootec., v.65, p.1247-1252, 2013.

DIVERS, S.J.; STAHL, S.J. Mader's reptile and amphibian - medicine and surgery. 3.ed. London: W.B. Saunders, 2019. 1512p.

DUTRA, G.H.P. Testudines (Tigre d'água, Cágado e Jabuti). In: CUBAS, Z.S.; SILVA, J.C.R.; CATÃO-DIAS, J.L. (Eds.). Tratado de animais selvagens - medicina veterinária. 2.ed (reimp.). São Paulo: Roca, 2020. 2492p.

FIGHERA, R.A.; SILVA, M.C.; SOUZA, T.M. et al. Aspectos patológicos de 155 casos fatais de cães atropelados por veículos automotivos. Cienc. Rural, v.38, p.1375-1380, 2008.

LOPES, E.R.; MORGADO, T.O.; MEIRELES, Y.S. et al. Ultrassonografia abdominal de tamanduás-bandeira (Myrmecophaga tridactyla Linnaeus, 1758) mantidos em cativeiro. Pesqu. Vet. Bras., v.35, p.919-924, 2015.
MITCHELL, M. Diagnostic imaging considerations for reptiles. 2009. Available in: http://veterinarycalendar.dvm360.com/avhc/cont ent/printContentPopup.jsp?id=607407. Accessed in: 7 Apr. 2021.

PINTO, A.C.B.C.F. Radiologia. In: CUBAS, Z.S.; SILVA, J.C.R.; CATÃO-DIAS, J.L. (Eds.). Tratado de animais selvagens - medicina veterinária. 2.ed (reimpr.). São Paulo: Roca, 2020. 2492p.

ROMERO, F.; ESPINOZA, A.; SALLABERRYPINCHEIRA, N. et al. A five-year retrospective study on patterns of casuistry and insights on the current status of wildlife rescue and rehabilitation centers in Chile. Rev. Chil. Hist. Nat., v.92, p.110, 2019.

THRALL, D.E. (Ed.). Textbook of veterinary diagnostic radiology. 6.ed. Saunders: Elsevier, 2014. 864p.

VALENTE, A.L.S. Diagnostic imaging of the Loggerhead sea turtle, Caretta caretta. 2007. 139f. Tese (Doutorado em Veterinária) Faculdade de Veterinária, Universidade Autônoma de Barcelona, Barcelona, ESP.

ZOLLER, G.; HAHN, H.; DI GIROLAMO, N. Technological advances in diagnostic imaging in exotic pet medicine. Vet. Clin. North Am. Exotic Anim. Pract., v.22, p.397-417, 2019. 